\title{
Projected future runoff of the Breede River under climate change
}

\author{
AC Steynor $^{1 *}$, BC Hewitson ${ }^{2}$ and MA Tadross ${ }^{3}$ \\ ${ }^{1}$ UK Climate Impacts Programme, School of Geography and the Environment, South Parks Road, Oxford, OX1 3QY, UK \\ ${ }^{2}$ Climate Systems Analysis Group, University of Cape Town, Rondebosch 7701, South Africa \\ ${ }^{3}$ Climate Systems Analysis Group, University of Cape Town, Rondebosch 7701, South Africa
}

\begin{abstract}
The Breede River is the largest river in the Western Cape Province of South Africa, and as such, is a key resource for a variety of activities within the region. It is this significance of the river that prompted a study into the impact of climate change on future runoff in the river and hence, the potential impacts a projected change in catchment runoff may have on the future use of the river. Due to the complexities of the catchment only specialised hydrological models can capture the system dynamics of the river adequately. This limitation prompted the use of an alternative approach (self-organising maps (SOMs)) to hydrological modelling and, at the same time, performed an assessment of the appropriateness of this alternative approach for use in such applications.

SOMs are a powerful tool in synoptic climatology as they can be used to objectively classify a large number of daily synoptic states into a predetermined number of groups. Each archetypal synoptic pattern is linked to an observed associated runoff in the catchment. With an assessment of the change in frequency of each atmospheric state from control to future comes an assessment of the change in frequency of the associated runoff from control to future. The end result of this is a quantified assessment of the projected change in both high-frequency runoff events and in the projected change in mean annual runoff (MAR) in the catchment from the present to the future under 3 climate models.

Not only does this information assist in the process of long-term policy decisions made in relation to water-transfer schemes, but it also allows for an assessment of the future ecological sustainability of the catchment. This is achieved by assessing the projected future level of flow at each runoff gauging station against the current benchmark for ecological sustainability.
\end{abstract}

Keywords: Breede River, runoff, climate change, ecological sustainability

\section{Introduction to the study area}

The Breede River, situated in the Western Cape, is the largest river in the province with a total catchment area of $12600 \mathrm{~km}^{2}$ (Fig. 1) comprising 7 drainage basins (DWAFa, 2002). The river lies on the east coast of the Western Cape, approximately $250 \mathrm{~km}$ from Cape Town, and extends from Cape Infanta up into the Hex River Mountains. Originating in the Ceres Valley, it drains in a south-easterly direction meeting the Indian Ocean at Witsand/Cape Infanta (Sebastian Bay) and flows through a key agricultural region in the Western Cape (DWAFb, 2002).

Being a winter rainfall region, roughly $80 \%$ of precipitation falls within the months of April to September, brought by midlatitude cyclones, which are dominant over the region in these months. As is the case with many mountainous areas, there is a considerable spatial variation in rainfall. In the Western mountain areas rainfall can be as high as $2300 \mathrm{~mm} / \mathrm{a}$ whereas in the middle reaches rainfall decreases to as low as $400 \mathrm{~mm} / \mathrm{a}$ (DWAFa, 2002).

Operation of the Breede River is such that water is collected during the winter period in municipal storage dams, such as Brandvlei and Theewaterskloof, for subsequent

\footnotetext{
* To whom all correspondence should be addressed.

용 +44 1865285532 or +44 7837657607; fax: +44 1865285710 ; e-mail: anna.steynor@ukcip.org.uk

Received 20 October 2008; accepted in revised form 23 April 2009.
}

dispersal during summer. A unique feature in the operation of the Theewaterskloof Dam is the transference of water into the dam from the Berg River water management area for seasonal storage, as the Berg River does not have sufficient storage capacity of its own in the form of dams and reservoirs. During the dry season, the water is then transferred back into the Berg River together with a large quantity of additional water from the Breede River in order to meet the demands for water from the Berg River (DWAFc, 2002).

It is this inter-basin transfer custom that prompted this study, which seeks to understand the sustainability of this practice under projected climate change. This paper attempts to quantify how the runoff in the Breede River will change in the future (without taking into account the possibility of future inter-basin transfers) and whether this runoff will be enough to sustain future ecological functioning. For the purposes of this study, runoff is defined as the amount of water flowing in the river at a stream gauge.

\section{Methodology}

\section{The Kohonen self-organising map}

Self-organising maps (SOMs) (Kohonen et al., 1996), which are a type of artificial neural network (ANN), are the principle technique used for the analysis of atmospheric data in this study. In this application, SOMs are used to downscale global climate model (GCM) data to catchment scale by relating 
catchment response to synoptic forcing. This technique simplified the use of large amounts of atmospheric data by enabling classification of a user-specified amount of synoptic circulation patterns. The intent in classification is to extend data records by use of a transfer function between the environmental parameter, in this case runoff, and the synoptic types. This circulation record can then be used to project the local environmental data into the future.

SOMs are a type of cluster analysis used to cluster similar properties into a pre-defined set of 'groups'. These 'groups', which are henceforth referred to as nodes, represent commonly occurring patterns in a multi-dimensional dataset (MacKellar et al., 2009). In creation of the SOM map each node is trained so that it is weighted by the input data vector that has the closest match to that node's synoptic state. In effect, when applied to time series of spatial data, the technique is analogous to cluster analysis to identify which spatial patterns are most similar in identifying dominant modes within the data space (Tennant, 2003)

Hewitson and Crance, 2002 and Dayhoff, 1990 identify aspects of the SOM behaviour that render it advantageous over traditional statistical methods. These identified strengths and the fact that they allow for the visualisation of an array of synoptic states by grouping large amounts of synoptic data into a specified amount of synoptic patterns or nodes makes them a powerful technique for use in climatology. The technique has a growing use in atmospheric applications (e.g. Main, 1997; Cavazos, 1999, 2000; Cavazos et al., 2002; Tennant and Hewitson, 2002; Hewitson and Crane, 2002; Tadross et al., 2006; Tennant and Reason, 2005; Thomas et al., 2007), both for up- and downscaling of atmospheric data (Crane and Hewitson, 2003; Gutiérrez et al., 2005; Hewitson and Crane, 2006) and identification of climatic regions (Malgrem and Winter, 1999).

A $7 \times 5$ SOM was defined for the purposes of this study. Crane and Hewitson (2003) have noted that the robustness of the SOM mapping is not sensitive to the array size - smaller SOM arrays merely generate a greater degree of generalization. Using a $7 \times 5$ array ( 5 nodes in the vertical row and seven nodes in the horizontal row) allows for 35 'arch-type' synoptic states to be identified in the SOM training. All data presented to the SOM were assigned to one of these nodes. Each node represents a state in the data space that is nominally the mean of all synoptic patterns mapping to the node after training. Nodes represented as diagonally opposite in the SOM map indicate the opposite extremes in the data and neighbouring nodes are indicative of the most similar data. Therefore, synoptic states that are dissimilar are widely separated over the SOM space and transitional states are represented between the groups (Hewitson and Crane, 2002).

\section{Climate data acquisition and SOM training}

In order to assess whether a consistent signal of climate change is portrayed by multiple climate models, 3 climate models have been chosen. For the purposes of this study the global climate models (GCMs) of ECHAM4 (developed by the Deutsches Klimarechenzentrum (DKRZ) in Hamburg, Germany and the Max Planck Institute for Meteorology) the CSIRO model (developed at Australia's Commonwealth Scientific and Industrial Research Organisation) and the HadAM model (developed at the Met Office Hadley Centre in the UK) were used along with the NCEP (National Centres for Environmental Prediction) reanalysis data (Kalnay et al., 1996). These GCMs were utilised because of the availability of data and their recognition within the Intergovernmental Panel on Climate Change (IPCC). NCEP reanalysis data (resolution of $2.5^{\circ} \times 2.5^{\circ}$ in latitude and longitude) is used as a proxy for the observed historical state of the atmosphere. It is constrained by observations but is a product of an atmospheric model. It was necessary to use proxy data because of a lack of contiguous observed data relating to atmospheric state.

What follows is a methodology that was developed in order to assess the accuracy of the GCM data in simulating observed atmospheric states and to assess the changes between the control and projected future climate data.

The NCEP data (used to represent the observed atmospheric state) were extracted for the years 1979 to 1999 for an atmospheric window situated over the Western Cape. The atmospheric window spans $12^{\circ}$ to $28^{\circ}$ in longitude and $-39^{\circ}$ to $-27^{\circ}$ in latitude. The 2 variables of geopotential height and specific humidity at $700 \mathrm{hPa}$, were chosen for extraction from the NCEP data because, together, they reasonably characterise the general atmospheric state related to rainfall. Using a rainfall-related synoptic state was more accurate than using modelderived precipitation data because of the high level of uncertainty in the parameterisations used to derive precipitation data from atmospheric models. This is justified and believed to promote consensus between GCMs because the models show more consensus in their predicted changes in atmospheric state than they do in their predicted changes of precipitation. The skill resolution of a GCM is greater in terms of base circulation parameters as opposed to grid-cell diagnostic variables such as precipitation (Hewitson and Crane, 2005).

NCEP data were used as input into the SOM, which was then trained to produce 35 archetypal patterns over a 7 x 5 SOM space. The result of this SOM training formed a baseline atmospheric state of simulated observed conditions thereby providing control synoptic conditions from which the deviation of the GCM data could be calculated.

Owing to the difference in the horizontal resolution of the GCMs and the NCEP reanalysis data, interpolation function grid-box averages were used to convert all the data to a common $4^{\circ} \times 3^{\circ}$ resolution. Data from the ECHAM4, CSIRO and HadAM models were individually mapped onto the NCEP-trained SOM to cluster the data into the NCEP-defined 35 archetypal patterns. Data from each of the GCMs encompassed a control climate ranging from 1979 to 1999 and a projected A2 (medium high) emission scenario (Nakic'enovic' et al., 2000) based future climate from 2079 to 2099 with the same variables and same domain as NCEP.

By using this technique to compare how data from each control run of the GCMs mapped to the NCEP-trained SOM one is firstly able to assess the GCM's ability to simulate present synoptic states. Secondly, how the future GCM data mapped to the same NCEP-trained SOM allowed an assessment of the potential future synoptic states. This analysis was performed for each GCM, in turn. This was a crucial step in the project as it provided a base from which to start analysis of the change in synoptic states from present to future and hence runoff patterns related to synoptic states. It is possible that the future climate will exhibit synoptic states that are not present in the baseline climate. This is a potential drawback of this technique and should be considered if the future data are obviously mapping too intensely to a node on the edge of the SOM map. This could be an indication that the data would map more readily to a synoptic state outside of the control climate. 


\begin{tabular}{|c|c|c|c|c|c|c|}
\hline \multicolumn{7}{|c|}{$\begin{array}{c}\text { TABLE } 1 \\
\text { Location of observation runoff stations and record period at each }\end{array}$} \\
\hline Station number & Place & Latitude & Longitude & $\begin{array}{l}\text { Catchment } \\
\text { area }\left(\mathrm{km}^{2}\right)\end{array}$ & $\begin{array}{l}\text { Record } \\
\text { period }\end{array}$ & Years \\
\hline H1H006 (Station 1) & Witbrug & $33^{\circ} 25^{\prime} 18^{\prime \prime}$ & $19^{\circ} 16^{\prime} 06^{\prime \prime}$ & 753 & $1950-1998$ & 48 \\
\hline H1H018 (Station 2) & Haweqias & $33^{\circ} 43^{\prime} 24^{\prime \prime}$ & $19^{\circ} 10^{\prime} 13^{\prime \prime}$ & 113 & $1969-1999$ & 30 \\
\hline H4H017 (Station 3) & Le Chasseur & $33^{\circ} 49^{\prime} 05^{\prime \prime}$ & 19॰41'41"' & 4336 & $1980-1998$ & 18 \\
\hline H6H009 (Station 4) & Reenen & $34^{\circ} 04^{\prime} 32^{\prime \prime}$ & $20^{\circ} 08^{\prime} 44^{\prime \prime}$ & 2007 & $1964-1998$ & 34 \\
\hline H7H006 (Station 5) & Swellendam & $34^{\circ} 03^{\prime} 57^{\prime \prime}$ & $20^{\circ} 24^{\prime} 15^{\prime \prime}$ & 9842 & $1967-1997$ & 30 \\
\hline
\end{tabular}

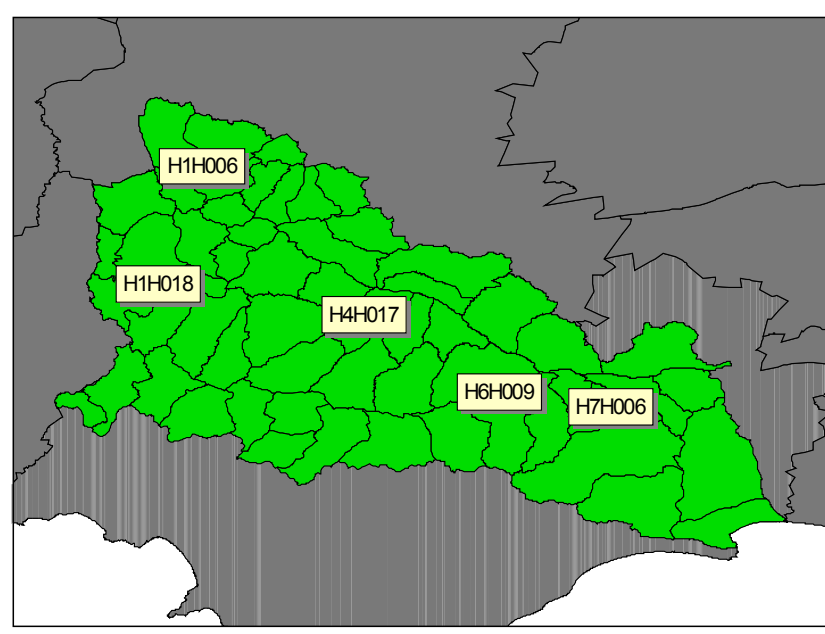

Figure 1

Location of observation runoff stations

\section{Runoff analysis}

\section{Runoff stations}

Raw runoff data from 5 stations in the catchment were obtained from the Department of Water Affairs and Forestry (DWAF). As shown in Fig. 1, two of the stations are in the upper reaches of the catchment (H1H006 and H1H018), one in the middle reaches (H4H017) and two in the lower reaches (H6H009 and H7H006). Table 1 is used to justify that all the stations have a long enough period of record to produce statistically significant results with the shortest period of record being 18 years and the longest 48 years.

\section{Analysis of the runoff associated with high frequency nodes}

As the SOM technique is a new methodology in identifying runoff change under a changing climate, an initial approach was taken to gauge the effectiveness of this technique. To this end an analysis was undertaken to assess what (according to the SOM) are the most frequently occurring synoptic states in the observed climate and what the most frequently occurring synoptic states may be in the future climate.

Before runoff could be associated with a synoptic event a determination had to be made as to whether there was a significant time lag between the particular atmospheric condition and the resultant runoff. By assessing the time lag between precipitation events and observed runoff, i.e. the response time of the catchment, the temporal relationship between rainfall and runoff was investigated. To assess the lag, precipitation data were extracted from a $10 \mathrm{~km}$ gridded data set of observed precipitation generated by Hewitson and Crane (2005). Precipita- tion was extracted for the upper reaches of the catchment (Basin H1) and compared to the runoff in that area, as it was necessary to get a natural rainfall-to-runoff relationship that represented least interference from dams or extraction. The treatment of the rainfall-to- runoff lag as being the same throughout the catchment does not have implications for the study because the future projections of climate are at a coarse GCM scale resulting in there only being one projection of future climate for the whole catchment for each GCM Due to the constraints inflicted by the Scoarseness of the future climate projection there can be no discrimination made about where in the catchment the rainfall has fallen, hence all rainfall to runoff lags are treated as equal. The lags were assessed through simple lagged correlation analysis.

With a one-day time lag between precipitation and the resultant runoff determined through this lagged correlation analysis (Steynor, 2005), a methodology was developed in order to associate runoff data with atmospheric conditions while using the SOM-based classification of the atmospheric circulation. The fundamental principle incorporated into a SOM is that each of the time steps over the 21-year period is associated with a node in the SOM space. Each node represents a particular atmospheric pattern. By identifying which dates were associated with each SOM node, the runoff for those dates can be associated with a specific atmospheric pattern. When the possibility of a lead-lag relationship between rainfall and runoff was accounted for, this provided the capacity to identify the typical runoff for a given atmospheric state.

By grouping together all the dates that fell into each SOM node, a box-and- whisker plot, showing the non-outlier ranges of the data at each station, was drawn. Outliers are, by definition, data points that do not appear to follow the characteristic distribution of the rest of the data. These may either reflect genuine properties of the data, or be due to measurement errors or other anomalies that should not be modelled. Generally, it is assumed that outliers depict a random signal that one would like to be able to control. In this case, the outlier data range was defined as above the $75^{\text {th }}$ percentile and below the $25^{\text {th }}$ percentile. A median or middle value was also depicted on the runoff graphs.

For each GCM and each period (control and future), the node showing the synoptic condition with the highest frequency of data mapping to it was selected as representative of the predominant synoptic condition. The runoff associated with the high frequency node in the control data was compared with the runoff associated with the high frequency node in the projected future scenario. By association of the runoff with the high frequency circulation states and the change in frequency of data mapping to each circulation state, one could infer, at least a first order, consequence on runoff of the projected changes in the atmosphere. The statistically relevant period of record at each runoff station allows the assumption that enough rainfall-runoff events are sampled to represent a range in catchment wetness conditions prior to rainfall commencement. 


\begin{tabular}{|c|c|c|c|c|}
\hline \multicolumn{5}{|c|}{$\begin{array}{c}\text { TABLE } 2 \\
\text { Decrease in runoff represented from node }(5 ; 2) \text { (control node) to node }(6 ; 2) \text { (projected future node) } \\
\text { according to the ECHAM4 model }\end{array}$} \\
\hline Median & Runoff node $(5 ; 2)\left(\mathrm{m}^{3} / \mathrm{s}\right)$ & Runoff node $(6 ; 2)\left(\mathrm{m}^{3} / \mathrm{s}\right)$ & Runoff change (m $3 / \mathrm{s})$ & Runoff change (\%) \\
\hline Station 1 & 0.65 & 0.00 & -0.65 & -100.00 \\
\hline Station 2 & 0.74 & 0.60 & -0.14 & -18.59 \\
\hline Station 3 & 7.05 & 6.37 & -0.68 & -9.65 \\
\hline Station 4 & 1.76 & 0.10 & -0.76 & -43.38 \\
\hline Station 5 & 4.91 & 3.62 & -1.29 & -26.17 \\
\hline $75^{\text {th }}$ percentile & Runoff node $(5 ; 2)\left(m^{3} / s\right)$ & Runoff node $(6 ; 2)\left(\mathrm{m}^{3} / \mathrm{s}\right)$ & Runoff change $\left(\mathrm{m}^{3} / \mathrm{s}\right)$ & Runoff Change (\%) \\
\hline Station 1 & 4.76 & 1.93 & -2.83 & -59.45 \\
\hline Station 2 & 2.82 & 1.12 & -1.70 & -60.28 \\
\hline Station 3 & 12.80 & 9.98 & -2.82 & -22.03 \\
\hline Station 4 & 13.80 & 4.97 & -8.83 & -63.99 \\
\hline Station 5 & 31.80 & 18.10 & -13.70 & -43.08 \\
\hline
\end{tabular}

\begin{tabular}{|c|c|c|c|c|}
\hline \multicolumn{5}{|c|}{$\begin{array}{c}\text { TABLE } 3 \\
\begin{array}{c}\text { Decrease in runoff represented from node }(4 ; 2) \text { (control) to node }(4 ; 3) \text { (projected future) } \\
\text { according to the CSIRO model }\end{array} \\
\end{array}$} \\
\hline Median & Runoff node $(4 ; 2)\left(\mathrm{m}^{3} / \mathrm{s}\right)$ & Runoff node $(4 ; 3)\left(m^{3} / s\right)$ & Runoff change (m $\left.{ }^{3} / \mathrm{s}\right)$ & Runoff change (\%) \\
\hline Station 1 & 0.96 & 0.71 & -0.25 & -25.64 \\
\hline Station 2 & 0.85 & 0.80 & -0.05 & -6.24 \\
\hline Station 3 & 7.19 & 6.82 & -0.37 & -5.08 \\
\hline Station 4 & 1.53 & 1.24 & -0.29 & -18.95 \\
\hline Station 5 & 6.01 & 4.41 & -1.60 & -26.64 \\
\hline $75^{\text {th }}$ percentile & Runoff node $(4 ; 2)\left(\mathrm{m}^{3} / \mathrm{s}\right)$ & Runoff node $(4 ; 3)\left(\mathrm{m}^{3} / \mathrm{s}\right)$ & Runoff change $\left(\mathrm{m}^{3} / \mathrm{s}\right)$ & Runoff change (\%) \\
\hline Station 1 & 6.11 & 4.99 & -1.12 & -18.33 \\
\hline Station 2 & 3.10 & 2.64 & -0.46 & -14.84 \\
\hline Station 3 & 15.70 & 13.00 & -2.70 & -17.2 \\
\hline Station 4 & 8.93 & 5.91 & -3.02 & -33.82 \\
\hline Station 5 & 30.10 & 21.10 & -9.00 & -29.90 \\
\hline
\end{tabular}

\section{Results of high frequency node analysis}

\section{ECHAM4}

Using the SOM technique described in the methodology the data from the ECHAM4 model were used to perform a highfrequency node analysis. This analysis is used to ascertain how the predominant synoptic state(s) in the observed climate may change in the future climate. Each node (representing a particular synoptic state) in the SOM map is assigned a number (x;y) depending on its position in the 7 x 5 SOM space with $\mathrm{x}$ representing its position on the horizontal row and $\mathrm{y}$ the position on the vertical row. In analysis of both the modelled control climate and the modelled future climate it was evident that the projected future data had a greater frequency of data falling into SOM node $(6 ; 2)$ as opposed to SOM node $(5 ; 2)$, which showed the majority of data mapping in the control frequency map. SOM node $(5 ; 2)$ represents a typically summer synoptic pattern with a low specific humidity over the Western Cape. Node $(6 ; 2)$ represents an intensification of this summer synoptic pattern.

When associating these 2 SOM nodes with a runoff characteristic it was possible to calculate a projected future runoff change for the high frequency node. Each runoff gauging station's percentage decrease in runoff from node $(5 ; 2)$ to node $(6 ; 2)$ is shown in Table 2 . The decrease was first calculated for the median and then for the upper limit of the non-outlier range (using box-and-whisker plots not shown here).

\section{CSIRO}

Using the same methodology, the CSIRO data were used to analyse potential future runoff in the high-frequency SOM node (Table 3). The change from the frequency map of CSIRO control data to the frequency map of CSIRO projected future data is only slight. The control to future map indicates a change of high frequency nodes from nodes $(4 ; 2)$ and $(4 ; 3)$ in the control map into solely node $(4 ; 3)$ in the frequency map of projected future data. This indicates that the predominant future daily synoptic state should exhibit an atmospheric pattern similar to that of node $(4 ; 3)$. Nodes $(4 ; 2)$ and $(4 ; 3)$ represent what could loosely be described as autumn/spring conditions with node $(4 ; 3)$ showing a slightly less specific humidity over the Western Cape.

\section{HadAM}

Again, using the same process as ECHAM4 and CSIRO, the HadAM data were used to perform an analysis on potential change in future runoff. The most obvious difference between the frequency map of control and future climate is the movement of the high frequency nodes from nodes $(5 ; 2)$ and $(5 ; 3)$ in the control data to nodes $(6 ; 2)$ and $(6 ; 3)$ in the projected future data. These latter nodes are also mapped at a higher frequency in the projected future data. To create a table of runoff values showing the magnitude of the decrease in runoff from the present to the projected future (Table 4) it was necessary to 


\begin{tabular}{|c|c|c|c|c|}
\hline \multicolumn{5}{|c|}{$\begin{array}{l}\text { TABLE } 4 \\
\begin{array}{l}\text { Decrease in runoff represented from node }(5 ; 2) \text { and }(5 ; 3) \text { (control) to nodes }(6 ; 2) \text { and }(6 ; 3) \\
\text { (projected future) according to the HadAM model }\end{array}\end{array}$} \\
\hline Median & Runoff node $(5 ; 2+5 ; 3)\left(\mathrm{m}^{3} / \mathrm{s}\right)$ & Runoff node $(6 ; 2+6 ; 3)\left(\mathrm{m}^{3} / \mathrm{s}\right)$ & Runoff change $\left(\mathrm{m}^{3} / \mathrm{s}\right)$ & Runoff change (\%) \\
\hline Station 1 & 0.66 & 0.00 & -0.66 & -100.00 \\
\hline Station 2 & 1.40 & 1.14 & -0.26 & -18.24 \\
\hline Station 3 & 13.70 & 12.76 & -0.94 & -6.86 \\
\hline Station 4 & 3.06 & 1.99 & -1.06 & -34.71 \\
\hline Station 5 & 8.67 & 6.56 & -2.12 & -24.39 \\
\hline $75^{\text {th }}$ percentile & Runoff node $(5 ; 2+5 ; 3)\left(\mathrm{m}^{3} / \mathrm{s}\right)$ & Runoff node $(6 ; 2+6 ; 3)\left(\mathrm{m}^{3} / \mathrm{s}\right)$ & Runoff change $\left(\mathrm{m}^{3} / \mathrm{s}\right)$ & Runoff change (\%) \\
\hline Station 1 & 7.47 & 2.97 & -4.50 & -60.24 \\
\hline Station 2 & 4.59 & 2.14 & -2.45 & -53.38 \\
\hline Station 3 & 23.80 & 20.08 & -3.72 & -15.63 \\
\hline Station 4 & 19.57 & 9.77 & -9.80 & -50.08 \\
\hline Station 5 & 44.80 & 27.93 & -16.87 & -37.66 \\
\hline
\end{tabular}

combine the runoff values of $(5 ; 2)$ and $(5 ; 3)$ to represent the present runoff and combine $(6 ; 2)$ and $(6 ; 3)$ to represent the future runoff. SOM nodes $(5 ; 2)$ and $(5 ; 3)$ represent a typically summer synoptic pattern with a low specific humidity over the Western Cape. Nodes $(6 ; 2)$ and $(6 ; 3)$ represent an intensification of this summer synoptic pattern.

This was just the first step in the analysis of the change in runoff from the control to the projected future data. It was primarily undertaken to assess the validity of the methodology. It was recognised that the high frequency nodes are not the only nodes likely to show a change in runoff under climate change (Barnett et al., 2006). If a currently low frequency node became a somewhat higher frequency node under climate change this could have a significant effect on projected future runoff. To account for this fact an assessment of the change in MAR over the entire SOM space was also included in the study. This did not serve to supersede the analysis of high frequency nodes (which represent the predominant synoptic states) but merely complement it.

\section{Results of MAR analysis}

In the previous results section it was determined that the nodes depicting a high frequency of data displayed a predominant decrease in runoff from the control to the projected future climate.

However, the high frequency nodes alone (the highest frequency synoptic events) cannot be used to calculate MAR because only one runoff regime is represented in each SOM node. In order to quantify the average runoff over the entire year it is necessary to consider every SOM node. To do this, the mean runoff values associated with each of the 35 synoptic states in the SOM map were incorporated into the analysis. Obviously, when each day is treated as a separate entity, a particular daily synoptic state will not always lead to the same amount of daily runoff because it will be dependent on the runoff in the catchment in the days leading up to the event. Hence, in order to do this analysis the assumption had to be made that the length of observed runoff periods used were long enough to give a reasonable impression of the mean observed runoff associated with a particular daily synoptic state. This assumption will mean that the MAR calculated using the SOM methodology will most likely not match exactly with the observed MAR but should be close enough to be relevant.

In order to calculate the MAR, the daily runoff values supplied by the Department of Water Affairs and Forestry (DWAF) and used in the previous section, were averaged and converted from $\mathrm{m}^{3} / \mathrm{s}$ into $10^{6} \mathrm{~m}^{3} / \mathrm{a}$. The second part of the calculation used the frequency maps for NCEP, ECHAM4, CSIRO and HadAM generated in the previous section. Each SOM node in the frequency maps represents a percentage of the data present across the SOM space. Therefore, by dividing these frequency values by 100 the proportional contribution of each SOM node could be determined.

If the proportional contribution of each SOM node is multiplied by the appropriate associated runoff and the results from each node across the SOM space summed together, the result is the MAR. Repetition of this process for each daily runoff gauging station determined the MAR for each station.

At the end of this process, the MAR values calculated using the NCEP reanalysis data and daily DWAF runoff data, although not expected to be the same, should have been representative of the original MAR data supplied by DWAF in the Breede River Basin Summary Report (DWAF, 2003). The supplied DWAF MAR values have been inserted into Table 5 for use as a reference.

Table 5, together with projected runoffs derived from the climate models, presents DWAF values for the following variables; the MAR presently observed in the river (Present MAR), what the runoff would be if there were no extractions or disturbances in the river (Natural MAR) and what level of runoff the ecology of the river requires to be able to sustain life and to provide a functioning ecosystem (ecological requirement) (DWAF, 2003).

There are some expected discrepancies between the calculated MAR using NCEP (used here to represent a control climate) and the MAR supplied by DWAF (Table 5) for 4 reasons. The $1^{\text {st }}$ reason is that the stations used to measure the DWAF MAR are only in approximately the same positions as the original daily runoff data stations. For instance the DWAF MAR sampling point that represents Station 2 is approximately $20 \mathrm{~km}$ away from the daily runoff station and the DWAF MAR sampling point that represents 4 is approximately $30 \mathrm{~km}$ away from the daily runoff station. The $2^{\text {nd }}$ reason is that NCEP is a reanalysis data set which exhibits a reduced variability owing to a truncation of processes that are smaller than the model resolution. In the $3^{\text {rd }}$ place, in reconstructing the MAR from the frequency of weather states, one is summing the mean runoff response for each weather state, not the actual observed instance of runoff for a particular occurrence of the weather state. The $4^{\text {th }}$ reason, as mentioned earlier, because the rainfall to runoff relationship is measured on a daily basis, it takes no 


\begin{tabular}{|c|c|c|c|c|c|}
\hline \multicolumn{6}{|c|}{$\begin{array}{c}\text { TABLE } 5 \\
\text { Comparison between the measured MAR data and the GCM-simulated MAR data }\end{array}$} \\
\hline DWAF (measured) & Station $1\left(10^{6} \mathrm{~m}^{3} / \mathrm{a}\right)$ & Station $2\left(10^{6} \mathrm{~m}^{3} / \mathrm{a}\right)$ & Station $3\left(10^{6} \mathrm{~m}^{3} / \mathrm{a}\right)$ & Station $4\left(10^{6} \mathrm{~m}^{3} / \mathrm{a}\right)$ & Station $5\left(10^{6} \mathrm{~m}^{3} / \mathrm{a}\right)$ \\
\hline Present MAR & 287.00 & 131.00 & 763.00 & \begin{tabular}{|l|}
94.00 \\
\end{tabular} & 1059.00 \\
\hline Natural MAR & 333.00 & 158.00 & 1210.00 & 347.00 & 1720.00 \\
\hline Ecological requirement & 84.00 & 79.00 & 552.00 & 134.00 & 623.00 \\
\hline Models & Station $1\left(10^{6} \mathrm{~m}^{3} / \mathrm{a}\right)$ & Station $2\left(10^{6} \mathrm{~m}^{3} / \mathrm{a}\right)$ & Station $3\left(10^{6} \mathrm{~m}^{3} / \mathrm{a}\right)$ & Station $4\left(10^{6} \mathrm{~m}^{3} / \mathrm{a}\right)$ & Station $5\left(10^{6} \mathrm{~m}^{3} / \mathrm{a}\right)$ \\
\hline NCEP (baseline climate) & 234.01 & 176.61 & 975.76 & 319.24 & 1178.27 \\
\hline ECHAM (control) & 218.58 & 160.67 & 917.42 & 289.11 & 1053.37 \\
\hline CSIRO (control) & 192.32 & 147.19 & 854.64 & 295.32 & 1039.86 \\
\hline HADAM (control) & 208.84 & 158.81 & 887.16 & 302.87 & 1079.19 \\
\hline
\end{tabular}

\begin{tabular}{|c|c|c|c|c|c|}
\hline \multicolumn{6}{|c|}{$\begin{array}{l}\text { TABLE } 6 \\
\text { Comparison between the GCM-simulated control MAR data and GCM-simulated future MAR }\end{array}$} \\
\hline Models & Station $1\left(10^{6} \mathrm{~m}^{3} / \mathrm{a}\right)$ & Station $2\left(10^{6} \mathrm{~m}^{3} / \mathrm{a}\right)$ & Station $3\left(10^{6} \mathrm{~m}^{3} / \mathrm{a}\right)$ & Station $4\left(10^{6} \mathrm{~m}^{3} / \mathrm{a}\right)$ & Station $5\left(10^{6} \mathrm{~m}^{3} / \mathrm{a}\right)$ \\
\hline ECHAM (control) & 218.58 & 160.67 & 917.42 & 289.11 & 1053.37 \\
\hline CSIRO (control) & 192.32 & 147.19 & 854.64 & 295.32 & 1039.86 \\
\hline HADAM (control) & 208.84 & 158.81 & 887.16 & 302.87 & 1079.19 \\
\hline ECHAM (future) & 94.90 & 76.03 & 424.06 & 180.33 & 565.23 \\
\hline CSIRO (future) & 204.9 & 154.48 & 902.24 & 298.90 & 1075.46 \\
\hline HADAM (future) & 140.34 & 113.24 & 625.53 & 263.44 & 842.09 \\
\hline
\end{tabular}

\begin{tabular}{|c|c|c|c|c|c|}
\hline \multicolumn{6}{|c|}{$\begin{array}{c}\text { TABLE } 7 \\
\text { Determination of unbiased projections of future mean annual runoff }\end{array}$} \\
\hline \multirow[t]{2}{*}{ Model } & \multicolumn{5}{|c|}{ MAR change $10^{6} \mathrm{~m}^{3} / \mathrm{a}$} \\
\hline & Station $1\left(10^{6} \mathrm{~m}^{3} / \mathrm{a}\right)$ & Station $2\left(10^{6} \mathrm{~m}^{3} / \mathrm{a}\right)$ & Station $3\left(10^{6} \mathrm{~m}^{3} / \mathrm{a}\right)$ & Station $4\left(10^{6} \mathrm{~m}^{3} / \mathrm{a}\right)$ & Station $5\left(10^{6} \mathrm{~m}^{3} / \mathrm{a}\right)$ \\
\hline ECHAM & -123.68 & -84.65 & -493.40 & -108.79 & -488.14 \\
\hline CSIRO & 12.58 & 7.29 & 47.60 & 3.58 & 35.61 \\
\hline HADAM & -68.51 & -45.57 & -261.64 & -39.43 & -237.09 \\
\hline \multirow[t]{2}{*}{ Model } & \multicolumn{5}{|c|}{$\%$ change } \\
\hline & Station $1 \%$ & Station $2 \%$ & Station $3 \%$ & Station $4 \%$ & Station $5 \%$ \\
\hline ECHAM & -56.58 & -52.68 & -53.78 & -37.63 & -46.34 \\
\hline CSIRO & 6.54 & 4.95 & 5.57 & 1.21 & 3.42 \\
\hline HADAM & -32.80 & -28.69 & -29.49 & -13.02 & -21.97 \\
\hline \multirow[t]{2}{*}{ Model } & \multicolumn{5}{|c|}{ Future MAR } \\
\hline & Station $1\left(10^{6} \mathrm{~m}^{3} / \mathrm{a}\right)$ & Station $2\left(10^{6} \mathrm{~m}^{3} / \mathrm{a}\right)$ & Station $3\left(10^{6} \mathrm{~m}^{3} / \mathrm{a}\right)$ & Station $4\left(10^{6} \mathrm{~m}^{3} / \mathrm{a}\right)$ & Station $5\left(10^{6} \mathrm{~m}^{3} / \mathrm{a}\right)$ \\
\hline ECHAM & 124.61 & 61.99 & 352.68 & 58.63 & 568.25 \\
\hline CSIRO & 305.77 & 137.49 & 805.50 & 95.14 & 1095.26 \\
\hline HADAM & 192.86 & 93.41 & 537.98 & 81.76 & 826.34 \\
\hline
\end{tabular}

account of the temporal nature of runoff and how runoff in the river may have been influenced by preceding days.

This difference in sampling points between the supplied MAR data and the daily runoff data (as mentioned above) may be part of the reason for these discrepancies between the MAR associated with the NCEP SOM and the observed MAR, particularly in Stations 2 and 4. The calculated control MAR data from the ECHAM4, CSIRO and HadAM GCMs are also not exactly the same as the calculated NCEP MAR data because the GCM data is model-dependent and not constrained by observations.

Future MAR values determined using the same process as for the control climate (Table 6) are an intermediary step to the final values because values generated by a GCM produce known differences (biases) in MAR relative to the observed present MAR.

The most reliable method of obtaining an unbiased projection for future MAR under each GCM is to calculate the percentage change in MAR between the control and the future GCM data. By subtracting the percentage change from the observed present MAR, a future unbiased MAR value can be determined. This method removes the associated biases in the GCMs. This process is shown in Table 7.

CSIRO reflects an increase in the MAR whereas both the other GCMs show the opposite result (Table 7). This can be partly explained by a small increase in frequency of data seen in nodes $(0 ; 0),(0 ; 1)$ and $(0 ; 2)$ in the future CSIRO SOM frequency map. These nodes did not influence the high-frequency node analysis because they do not express the highest frequency of data mapping. These nodes were explained earlier to be 'winter' nodes, therefore exhibiting winter rainfall patterns with elevated runoff. This result could be due to the fact that CSIRO is recognised not to model the statistics of the Western Cape rainfall well (Steynor, 2002). The Western Cape exhibits a Mediterranean climate which is unlike the rest of South Africa. The CSIRO model does not reflect this intricacy and 


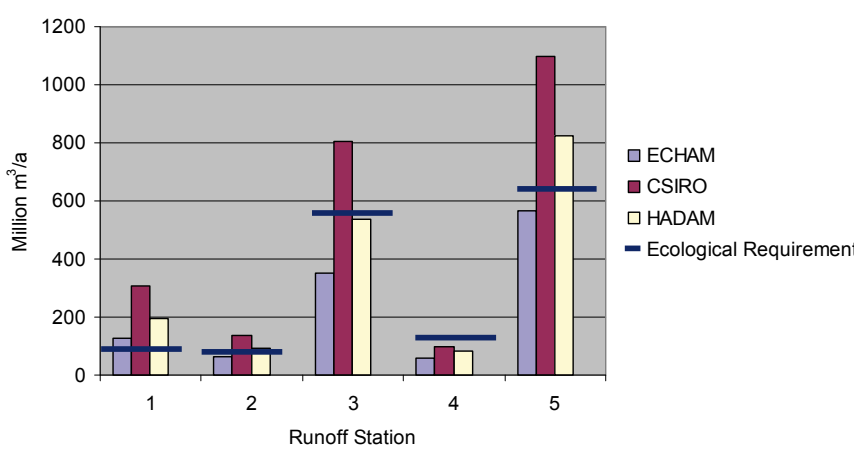

Figure 2

Projected future runoff in comparison to ecological requirement

models a bimodal annual rainfall pattern with peak rainfalls falling in summer; this is not representative of the Western Cape climate.

The ECHAM4 and HadAM models, however, exhibit a decrease in the MAR from the present to the projected future scenario, which is more in line with the high frequency node analysis. An assessment can now be made as to whether the future projected MAR for these models falls below the ecological requirement expressed in Table 5.

\section{Analysis of ecological requirement}

In the ecological sustainability analysis (Fig. 2) the data associated with Station 1 in the upper catchment, indicate that none of the models exhibit a projected MAR that falls below the ecological requirement of $84 \times 10^{6} \mathrm{~m}^{3} / \mathrm{a}$ by the $2080 \mathrm{~s}$. However, at the other upper catchment Station 2, the ECHAM4 Model does show a projected future MAR that is lower than the ecological requirement of $79 \times 10^{6} \mathrm{~m}^{3} / \mathrm{a}$, with the other 2 models still demonstrating an ecologically sustainable runoff. At the middle catchment, Station 3, both the models of ECHAM4 and HadAM exhibit a projected future MAR that is less than the ecological requirement of $552 \times 10^{6} \mathrm{~m}^{3} / \mathrm{a}$. The lower catchment, Station 4, already displays a current MAR of less than the ecological requirement of $134 \times 10^{6} \mathrm{~m}^{3} / \mathrm{a}$. Obviously, this deficit will only worsen across most of the models in the projected future scenario. At the final, Station 5, ECHAM4 shows a future runoff that is projected to be lower than that of the $623 \times 10^{6} \mathrm{~m}^{3} / \mathrm{a}$ ecological requirement.

This projection is especially disturbing considering that, within the constraints of this paper, only future climate changes are taken into account. No secondary impacts on runoff in the river, such as increased extraction for agriculture or domestic demands, are accounted for. These secondary impacts may further modify the amount of water flowing in the river, thereby pushing the ecosystem closer to environmentally sustainable thresholds, or perhaps improving resilience

\section{Discussion}

Despite the necessary assumptions made throughout this study, there are some significant implications for water management in the Breede River. Water managers must plan for a projected decrease in the overall runoff in the river under climate change as a consequence of an increase in the frequency of particular synoptic conditions associated with lower runoff. At some stations this also means planning for a potential loss in ecological sustainability.
Uncertainty is an integral part of any climate change research because it is never possible to perfectly predict the future (Dessai et al., 2008). There were a number of assumptions (with associated uncertainties) that needed to be made in this project in order to make the research possible. This work only reflects the SRES A2 climate scenario (Nakic'enovic' et al., 2000). Emissions are currently actually tracking a higher emission pathway than this (Raupach et al., 2007). In order to improve the certainty of these results within the envelope of possible future scenarios, further SRES scenario data could be investigated using the same methodology as this study. However, this is not the only research that has shown similar consequences on water supply in the Western Cape. Amongst other research, a study conducted by New (2002) concluded that the decrease in water supply and increase in demand in the Western Cape would exacerbate the existing water resource problems in the region. Even with 'moderately effective' water demand management it is likely that future water demand will exceed supply (Cape Metropolitan Council, 2001). New (2002) also stressed the need for the inclusion of climate change projections in long-term planning. This is already a requirement in the United Kingdom and is urgently needed in water-stressed regions such as the Western Cape (OFWAT, 1998).

The agreement of this research with similar research conducted on other Western Cape rivers demonstrates that SOMs are an effective method for use in hydrological research. SOMs are statistically based but require less computational and hydrological knowledge than using a specialised hydrological model. The SOM method applied in this project represents a relatively new methodological option for future hydrological research.

There is still further work that can be undertaken in this area. For instance, land-use impacts on runoff should be further investigated in order to reduce uncertainty in projected runoff. These were not included within the scope of this project; however, even without including the land-use impacts, it is still evident that climate change will have a significant impact on runoff in the Breede River.

\section{References}

BARNETT D, BROWN S, MURPH, J SEXTON D and WEBB M (2006) Quantifying uncertainty in changes in extreme event frequency in response to doubled $\mathrm{CO}_{2}$ using a large ensemble of GCM simulations. Clim. Dyn. 26 (5) 489-511.

CAPE METROPOLITAN COUNCIL (2001) Water Services Development Plan (Internal report). Cape Metropolitan Council, City of Cape Town, South Africa.

CAVAZOS T (1999) Large-scale circulation anomalies conducive to extreme precipitation events and derivation of daily rainfall in north-eastern Mexico and south-eastern Texas. J. Clim. 12 15061523.

CAVAZOS T (2000) Using self-organizing maps to investigate extreme climate events: and application to wintertime precipitation in the Balkans. J. Clim. 13 1718-1732.

CAVAZOS T, COMRIE A and LIVERMAN D (2002) Intraseasonal variability associated with wet monsoons in southeast Arizona. J. Clim. 15 2477-2490.

CRANE R and HEWITSON B (2003) Clustering and upscaling of station precipitation records to regional patterns using self-organizing maps (SOMs). Clim. Res. 25 95-107.

DAYHOFF J (1990) Neural Network Architectures: An Introduction. Van Nostrand Reinhold. New York. 259 pp.

DEPARTMENT OF WATER AFFAIRS AND FORESTRY (2002a) Breede River Basin Study. Hydrology Second Draft. Prepared by Ninham Shand. DWAF Report No. P H 000/8718. DWAF, Pretoria, South Africa. 
DEPARTMENT OF WATER AFFAIRS AND FORESTRY (2002b) Breede River Basin Study. Agricultural Water Demand. Prepared by L Bruwer of Louis Bruwer Inc. DWAF Report No. PH 00/00/1802. DWAF, Pretoria, South Africa.

DEPARTMENT OF WATER AFFAIRS AND FORESTRY (2002c) Proposed $1^{\text {st }}$ edn. National Water Resource Strategy. DWAF, Pretoria, South Africa.

DEPARTMENT OF WATER AFFAIRS AND FORESTRY (2003) Summary Report. Prepared by H Beuster and M J Shand of Ninham Shand (Pty) Ltd as Part of the Breede River Basin Study. DWAF Report No. P H 00/00/3302. DWAF, Pretoria, South Africa.

DESSAI S, HULME M, LEMPERT R and PIELKE R (Jr.) (2009) Climate prediction: a limit to adaptation? In: Adger W, Lorenzoni I and O'Brien K (eds.) Adapting to Climate Change: Thresholds, Values, Governance. Cambridge University Press. 64-78.

GUTI ÉRREZ J, CANO R, COFINO A and SORDO C (2005) Analysis and dowscaling multi-model seasonal forecasts in Peru using self-organizing maps. Tellus 57A 435-447.

HEWITSON B and CRANE R (2002) Self-organizing maps: Applications to synoptic climatology. Clim. Res. 22 13-26.

HEWITSON B and CRANE R (2005) Gridded area average daily precipitation via conditional interpolation. J. Clim. 18 41-57.

HEWITSON B and CRANE R (2006) Consensus between GCM climate change projections with empirical downscaling: precipitation downscaling over South Africa. Int. J. Clim. 26 (10) 1315-1337.

KALNAY E, KANAMITSU M, KISTLER R, COLLINS W, DEAVEN D, GANDIN L, IREDELL M, SAHA S, WHITE G, WOOLLEN J, ZHU Y, LEETMAA A, REYNOLDS B, CHELLIAH M, EBISUZAKI W, HIGGINS W, JANOWIAK J, MO K, ROPELEWSKI C, WANG J, JENNE R and JOSEPH D (1996) The NCEP/NCAR 40-year reanalysis project. Bull. Am. Met. Soc. 77 437-471.

KOHONEN T, HYNNINEN J, KANGAS J and LAAKSONEN J (1996) SOM_PAK: The Self-Organizing Map Program Package. Helsinki University of Technology, Helsinki, Finland.

MACKELLAR N, TADROSS M and HEWITSON B (2009) Synopticbased evaluation of climatic response to vegetation change over southern Africa. Int. J. Clim. DOI: 10.1002/joc.1925.

MAIN J (1997) Seasonality of Circulation in Southern Africa Using the Kohonen Self-organising Maps. M.Sc. Thesis. University of Cape Town, Cape Town, South Africa.
MALGREM B and WINTER A (1999) Climate zonation in Puerto Rico based on principle component analysis and an artificial neural network. J. Clim. 12 977-985.

NEW M (2002) Climate Change and Water Resources in the southwestern Cape, South Africa. S. Afr. J. Sci. 98 369-376.

NAKIC'ENOVIC' N, DAVIDSON O, DAVIS G, GRÜBLER A KRAM T, LA ROVERE E, METZ B, MORITA T, PEPPER W, PITCHER H, SANKOVSKI A, SHUKLA P, SWART R, WATSON $\mathrm{R}$ and DADI Z (2000) IPCC Special Report on Emission Scenarios. Cambridge University Press, Cambridge. United Kingdom and New York. USA, 599 pp.

OFWAT (1998) Setting Price Limits for Water and Sewerage Services: The Framework and Business Planning Process for the 1999 Periodic Review. Office of Water Services. Birmingham, United Kingdom.

RAUPACH M, MARLAND G, CIAIS P, LE QUERE C, CANADELL J, KLEPPER G and FIELD C (2007) Global and regional drivers of accelerating $\mathrm{CO}_{2}$ emissions. Proc. Natl. Acad. Sci. 104 (24) 10288-10293.

STEYNOR A (2002) The Impact of Global Climate Change on Apple Farming: A Study of the Overberg. B.Sc. (Hons) Thesis. University of Cape Town, Cape Town, South Africa.

STEYNOR A (2005) The Impact of Global Climate Change on the Runoff and Ecological Sustainability of the Breede River. M.Sc. Thesis. University of Cape Town, Cape Town, South Africa.

TADROSS M, GUTOWSKI W, HEWITSON B, JACK C and NEW M (2006) MM5 simulations of interannual change and the diurnal cycle of Southern African regional climate. Theor. Appl. Clim. 86 63-80.

TENNANT W (2003) An assessment of intra-seasonal variability from 13-year GCM simulations. Mon. Weather. Rev. 131 1975-1991.

TENNANT W and HEWITSON B (2002) Intraseasonal rainfall characteristics and their importance to the seasonal prediction problem. Int. J. Clim. 22 1033-1048

TENNANT W and REASON C (2005) Associations between the global energy cycle and regional rainfall in South Africa and southwest Australia. J. Clim. 18 3032-3047.

THOMAS C, TWYMAN C, OSBAHR H and HEWITSON B (2007) Adaptation to climate change and variability: farmer responses to intra-seasonal precipitation trends in South Africa. Clim. Change 83 301-322. 